\title{
Estudio multicéntrico prospectivo con implantes MG-OSSEOUS a los 2 años de seguimiento
}

\section{Multicentric prospective study of MG-OSSEOUS implants at 2 year follow-up}

\author{
E. Serrano', R. Martín-Granizo²
}

Resumen: Introducción. La implantología es uno de los procedimientos terapéuticos más realizados en nuestros días. El objetivo del presente estudio es presentar los resultados de los los implantes MG-OSSEOUS (Mozo-Grau, S.L., Valladolid, España) a los 2 años de seguimiento. Material y método. La empresa Scientific Management in O\&SS (Barcelona, España), diseñó unos cuestionarios exhaustivos que rellenaron, por cada caso, cada uno de los profesionales del estudio. La compilación y el tratamiento estadístico de los datos obtenidos fue extremadamente pormenorizada. Se aplicaron estudios de subpoblaciones desde la población $\mathrm{N}$ de implantes totales colocados $\mathrm{y}$, mediante la aplicación de ANOVA, se valoraron parámetros concretos en dichas subpoblaciones para determinar y concluir la influencia de los mismos sobre el fracaso de los implantes. Resultados. Se colocaron 1475 implantes en 480 pacientes entre Junio de 2005 y Mayo de 2006, con una supervivencia del $98,2 \%$ con un seguimiento de 2 años de promedio con las prótesis cargadas. Se detallan los implantes por posiciones, diámetros y longitudes y se analizan los resultados en las subpoblaciones de implantes postexodoncia, implantes de carga inmediata e implantes asociados a injertos. Discusión. Se focaliza, realizando un amplio repaso de la bibliografía actual, en el alto fracaso obtenido en nuestro estudio de los implantes de diámetro ancho $(4,25 \mathrm{~mm})$ postexodoncia y en la versatilidad del empleo de los implantes de diámetro estrecho (3,4 mm) en cualquier posición oral para cualquier tipo de carga. Conclusiones. Este estudio es la completa antítesis de la filosofía, en el que se interpreta de una sola manera, científica y reproducible, una serie de resultados en el campo de la implantología oral, nuestra realidad. Seguiremos este estudio para alargar el tiempo observacional, como mínimo, a 5 años.

Palabras clave: Implantes dentales; Edentulismo; Titanio; Implantes autoroscantes

Recibido: 24.06.2009

Aceptado: 30.10.2009

1 Cirujano oral y maxilofacial. Práctica privada de cirugía maxilofacial e implantes, Barcelona. España

2 Médico adjunto. Servicio de cirugía oral y maxilofacial. Hospital Clínico San Carlos, Madrid. España

\section{Correspondencia:}

C/ Gran Via Carles III 58-60, esc A. At 1 o

08028 Barcelona. España

Email: 31188esc@comb.es

\begin{abstract}
Introduction. Implantology is the most common therapeutic procedure nowadays. Professor P.I. Branemark began this procedure in 1965 and got very bad results. Since the Harvard Consensus Conference, 30 years ago, showing and explaining the surprising criteria of the implant's survey, until now we have moved to the opposite side. All the rules are broken and they try to convince you by publishing some trials that are not scientific enough. We present this truly scientific trial using MG-OSSEOUS implants (MozoGrau SL, Valladolid, Spain) as a humble contribution, based on well defined and realistic clinical uses. Material and methods. The Spanish company Scientific Management in O\&SS (Barcelona) designed a complete questionnaire to be completed by the implantologist dealing with each clinical case. The compilation and statistical processing were extremely rigorous. Data was managed, from the total rate of implants $(N)$, to conclude if it was possible to obtain true data of different samples, and using ANOVA, to analyze selected parameters from these samples, in order to see the direct relation between them and the failure of the implants. Results. 1,475 dental implants were placed in 480 patients, between June 2005 and May 2006. The global implants success rate was $98.2 \%$ with an average of 2 years follow-up with the connected prostheses. The implants' position, length and diameter are detailed and the samples are also analyzed, as post extraction implants, immediate loading implants and implants associated with grafts. Discussion. We focused on, completing an exhaustive revision of actual bibliographical sources, the high failure rate obtained by the wide diameter implants $(4,25 \mathrm{~mm})$ post extraction and on the versatility of the strength diameter implants $(3,4 \mathrm{~mm})$ to be placed anywhere in the mouth, with no mean of the type of prosthesis associated. Conclusions. This trial can be defined as the philosophy's antithesis, in which we allow scientific and reproducible conclusions in implant surgery, our scientific truth. We will extend this trial to reach, at least, 5 years of follow-up.
\end{abstract}

Key words: Dental implants; Edentulism; Titanium; Self-tapped implants 


\section{Introducción}

La implantología dental es uno de los procedimientos terapéuticos más realizados en la actualidad para la rehabilitación de la boca. Tal vez se haya perdido la perspectiva real de esta técnica y con frecuencia nos encontramos sobreindicaciones de este procedimiento, muchas de ellas avaladas por estudios clínicos poco consistentes y con dudosa validez científica, a veces contaminados por oscuros intereses comerciales.

Ni medio siglo hace, desde el año 1965, que el profesor P.I. Branemark, cirujano ortopeda, empezó a colocar implantes en pacientes tras un sorprendente hallazgo casual en conejos, con los consiguientes problemas que una técnica, todavía, precaria, ocasionaba a los pacientes y a los odontólogos suecos de la época. Y apenas 30 años de la Harvard's Consensus Conference, en la cual se estipulaba como criterios de éxito de los implantes, una reabsorción ósea de menos de un tercio de la longitud del implante y una movilidad del mismo de $1 \mathrm{~mm}$. (Albrektsson y Wennerberg 2005).

Hay numerosas casas comerciales que han publicado sus estudios sobre implantes dentales, aunque hay una gran variedad de trabajos, resultados y metodología empleada en la literatura científica, lo cual no permite sacar conclusiones fiables que no estén empañadas por intereses comerciales.

En este estudio multicéntrico prospectivo, realizado con implantes MG-OSSEOUS (Mozo-Grau S.L., Valladolid, España), han participado un grupo de profesionales, realizando una implantología bien planteada y responsable, sin técnicas aventuradas ni procedimientos heroicos. Esta conclusión se extrae tras el análisis exhaustivo de los cuestionarios completados por dichos profesionales, en los que se detallaba cada detalle del planteamiento implantológico en cada paciente. El objetivo del presente artículo es mostrar los resultados a medio plazo (dos años de seguimiento) obtenidos con los implantes MG-OSSEOUS colocados en diferentes situaciones entre los años 2005 y 2006. Este implante es un implante cónico, autorroscante, de titanio puro y con un tratamiento de superficie tipo RBM (siglas en inglés de arenado con medios reabsorbibles) que se altera con medios biocompatibles (cerámica de fosfato de calcio); la conexión es de hexágono externo compatible.

Sirva entonces este estudio como modesta aportación para reconocer y centrar las directrices de la implantología exitosa, basándose en criterios estables y estudios honrados.

\section{Material y método}

El diseño y desarrollo de este estudio multicéntrico fue dirigido por una empresa independiente y especializada en este tipo de análisis y sin relación con el fabricante del material, Scientific Management in O\&SS S.L. (Barcelona, España), Se emplearon implantes dentales MG-OSSEUS (Mozo-Grau S.L., Valladolid, España).

Tras analizar las variables a estudiar, se elaboró un detallado cuestionario (Fig. 1) que se envió a cada uno de los profesionales que aceptaron sin intereses comerciales tomar parte en el presen-

\section{Introduction}

Dental implant is one of the most common therapeutic procedures used in mouth rehabilitation. Perhaps the real perspective of this technique has been lost and we often find indicators of this procedure, many of them guaranteed by clinical studies that are not very consistent and whose scientific validity is doubted. Sometimes they are even contaminated by commercial interests.

Not even half a century since 1965 when Professor P.I. Branemark, orthopedic surgeon, started to give implants to patients after he made an accidental discovery in rabbits. There were problems with the still precarious technique that caused by Swedish patients and doctors from that time. Almost 30 years of Harvard's Consensus Conference where successful implant criteria were stipulated, bone reabsorbing of less than one third of the length of the implant and its mobility of $1 \mathrm{~mm}$. (Albrektsson and Wennerberg 2005).

There are a lot of commercial houses that have published studies about dental implants. Although there is a great variety of work, results and methodology used in scientific literature the published works don't allow us to draw concrete conclusions that are not corrupted by commercial interests.

In this multicentric prospective study, carried out with MG OSSEOUS implants (Mozo-Grau S.L. Valladolid, Spain) a group of professionals have participated, performing a well discussed and responsible implant, without dangerous or heroic procedures. This conclusion is drawn after exhaustive analysis of the completed questionnaires that these professionals filled out. The questionnaires documented implant details for each patient. The purpose of this article is to show the results after a two year follow-up obtained with MGOSSEOUS implants that were placed in different situations between 2005 and 2006. This implant is a conic implant AUTORROSCANTE, made of pure titanium and with RBM surface treatment that is altered with biocompatible measures (calcium phosphate ceramic); the connection is made of compatible external hexagon.

This study is a modest contribution to recognize and concentrate the diretrix of successful implantation, based on stable criteria and honest studies.

\section{Materials and method}

The design and development of this multicentric study was directed by a business that is independent and specialized in this type of analysis and there is no relation with the maker of the material, Scientific Management in O\&SS S.L. (Barcelona, Spain). Dental implants MG-OSSEUS (MozoGrau SL, Valladolid Span) were used.

After analyzing the variables to study a detailed questionnaire (Fig. 1) was designed and sent to each one of the professionals that had agreed to take part in this study with- 


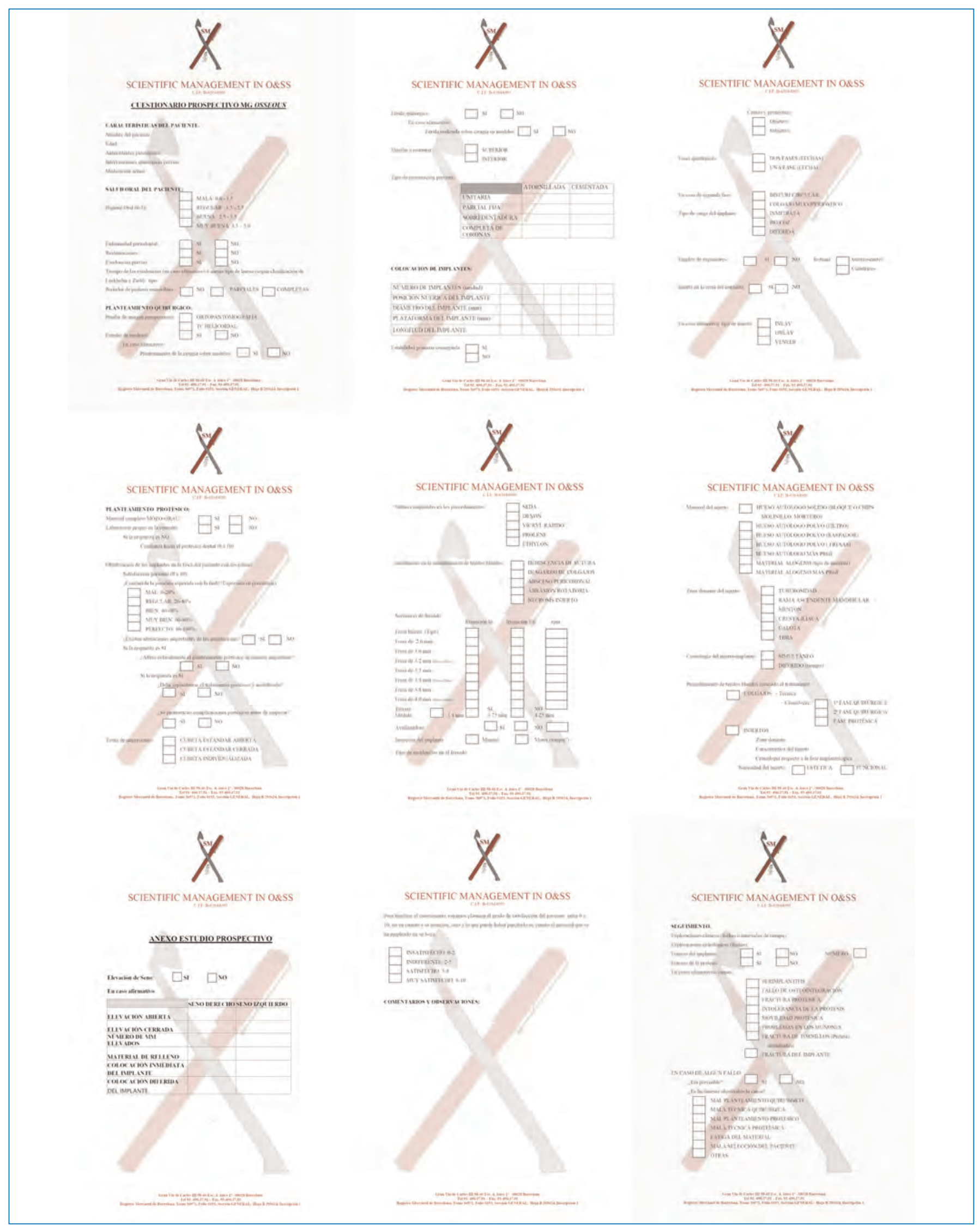

Figura 1. Cuestionario detallado que ha sido cumplimentado para este estudio.

Figure 1. Detailed questionnaire that was completed for this study. 
te estudio. Con este cuestionario se pretendía recabar una completa información, que incluía:

- Estado de salud del paciente (antecedentes médicos y salud oral).

- Estudio preoperatorio (pruebas complementarias, férulas, análisis del tipo de hueso según la clasificación de Leckholm y Zarb (1989), el maxilar a restaurar, prótesis prevista)

- Colocación del implante (longitudes, diámetros, técnicas explícitas, suturas empleadas).

- Injertos asociados (óseos, tejidos blandos, zonas donantes).

- Planteamiento protésico (material empleado, percepción de complicaciones, toma de medidas, diseño protésico).

- Satisfacción tanto del paciente como del implantólogo (expresada en una escala objetivable y reproducible)

- Detalle de las complicaciones durante y después del tratamiento.

- Apartado especial para observaciones particulares en cada caso.

Los profesionales que intervinieron en el estudio rellenaron un cuestionario por cada paciente.

Los casos fueron realizados entre mayo de 2005 y junio de 2006. Todos los pacientes han sido controlados hasta la fecha de hoy, sin reportar nuevas incidencias.

Los datos de los cuestionarios fueron recogidos por dos personas y plasmados en unas tablas especialmente diseñadas para el caso. Una de ellas no tenía ningún conocimiento de implantología, por lo que, el contraste entre las dos personas encargadas de la recogida y clasificación de los datos, permitía obviar el sesgo de información u observación. El tratamiento de los datos fue realizado de manera objetiva sin extrapolar ni suponer un solo resultado que beneficiase o perjudicase el estudio. Esta objetividad llevó a descartar 49 implantes, en los que no se refería fracaso alguno, por deficiencias en la cumplimentación de los cuestionarios.

Además, no se ha podido determinar la proporción entre mujeres y hombres, ya que en los cuestionarios no constaban los nombres de los pacientes y, en más de un $45 \%$, no se había detallado el sexo.

Cuando definimos fracaso en este estudio, lo hacemos como la caída o pérdida de estabilidad del implante, aunque se tuvieron en cuenta los criterios definidos por Smith y Zarb en 1989. out commercial interests. This questionnaire was used to collect complete information that included:

- Patients state of health (prior medical and oral health conditions).

- Preoperative state (complimentary tests, ferules, bone analysis according to the Leckholm and Zarb classification (1989), restoring the maxilla, previewed prosthesis).

- Implant placement (lengths, diameters, explicit techniques, stitches used).

- Associated grafts (bones, soft tissues, donor zones).

- Prosthetic plantation (materials used, complications, taking measurements, prosthetic design).

- Patient and Doctor satisfaction (expressed on a objective and reproducible scale).

- Detailed complications during and after treatments.

- Detail of complications during and after treatment.

- Special box for particular observations in each case for observations.

The professionals that intervened in this study filled out the questionnaire for each patient. The cases were carried out between May 2005 and June 2006. All of the patients have been controlled up until today's date without reporting any new incidences.

The data from the questionnaire was collected by two people and materialized into tables specially designed for this case. One of had no knowledge of implantology, the contrast between the two people in charge of collecting and classifying the information would make it very difficult for the skewing of information to go unnoticed.. The treatment of the data was carried out objectively without extrapolating or supposing any results that would benefit this study. 49 implants cases were not included in the study because their questionnaires were not filled out properly.

We could not determine the proportion of men and women since the questionnaires did not include the names of the patients and $45 \%$ of patients did not report their sex. 
El protocolo de estudio aplicado a cada caso fue exhaustivo e incluía:

- Ortopantomografia en todos los pacientes.

- TC helicoidal (dentaescan) cuando se empleaban injertos y cuando se quería tener un exacto control sobre el canal del nervio alveolar inferior. En casos con disponiblidad de hueso más favorable se hacía una evaluación clínica sin TC.

- Estudio de modelos en todos los casos de diseño de prótesis completas o híbridas, así como en carga inmediata para prótesis parciales fijas, completas o híbridas.

- Cirugía sobre modelos en casos de carga inmediata para prótesis parciales fijas, completas o híbridas.

- Férula quirúrgica en aquellos casos de carga inmediata o diferida, en el $17,4 \%$ de los implantes.

El objetivo de este estudio es valorar la supervivencia de los implantes colocados. Al tratarse de un estudio sobre 1.475 implantes, población $\mathrm{N}$ global, colocados siguiendo diferentes indicaciones y técnicas, planteamos un tratamiento estadístico exhaustivo, que se les detalla a continuación.

El primer objetivo era realizar el cálculo para determinar, desde una población $\mathrm{N}$ de implantes totales, la creación muestras dependientes ( $\mathrm{n}$ ) con un suficiente número de implantes en cada una, como para obtener resultados estadísticamente válidos e independientes de la población inicial. Todo ello con el fin de realizar estudios de supervivencia independientes de las diferentes muestras consideradas, carga inmediata $\left(n_{i}\right)$ y postexodoncia $\left(n_{p}\right)$. Para este fin, aplicamos las siguientes consideraciones (Pita 1995):

- Para obtener el tamaño de la muestra se debe definir cual va a ser el error estándar para obtener a partir de allí la varianza y establecer la fluctuación de $\exists$ (valor promedio de una variable) con respecto a \# (valor promedio de la misma variable en la población N).

- Por otra parte, una vez se ha objetivado si de la población $\mathrm{N}$ de implantes podemos crear subpoblaciones independientes y representativas, estudiamos el fracaso de esos implantes en cada una de ellas, mediante el empleo del análisis normal de la varianza (ANOVA), tomando como parámetros comparativos dos factores bien detallados en nuestro cuestionario: la higiene del

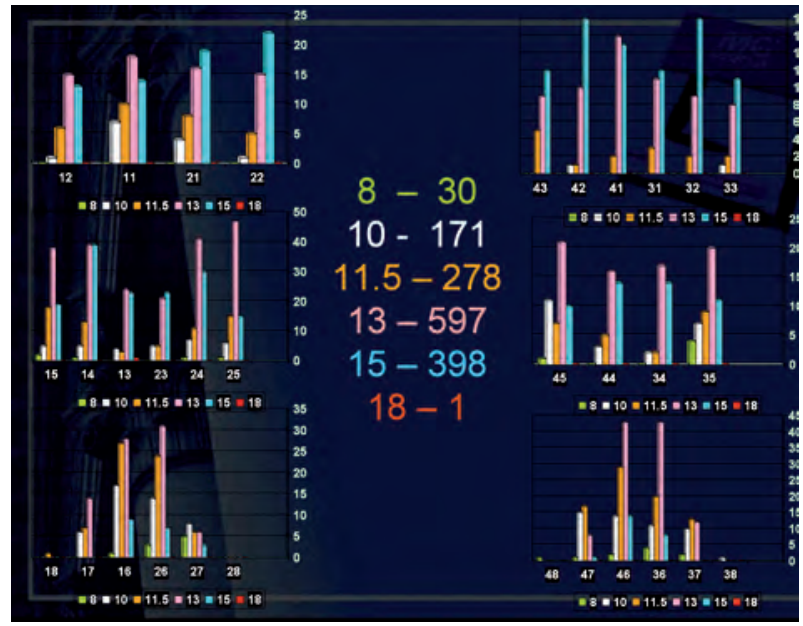

Figura 5. Distribución de las longitudes de los implantes en todas las posiciones orales. Población $\mathrm{N}$ de los implantes desglosada por longitudes. Los más colocados fueron los implantes de 13 y $15 \mathrm{~mm}$. implants. Population $\mathrm{N}$ of the implants by length. The most placed

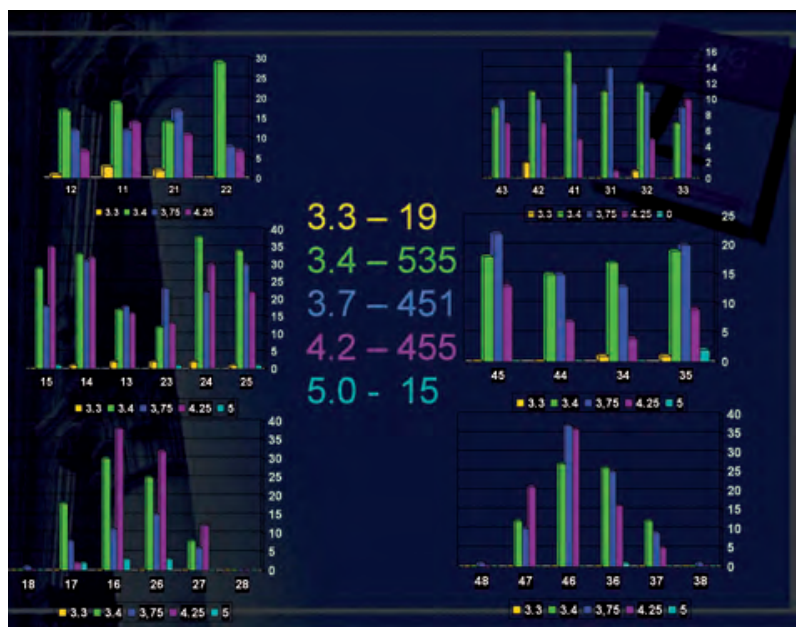

Figura 6. Distribución de los implantes según sus diámetros en las diferentes posiciones. Población $\mathrm{N}$ de los implantes desglosada por diámetros. Los más empleados los implantes de $3,4 \mathrm{~mm}$. Figure 6. Distribution of the implants according to their different diameters and positions. Population $N$ of the implants "desglosada by diameters. The most used implants were $3.4 \mathrm{~mm}$.
In this study when we define failure we do so as decrease or loss of implant stability, even though they take into account the criteria defined by Smith and Zarb in 1989.

The protocol in this study is applied to each case was exhaustive and included:

- Orthopantogram of all the patients

- Helicoid CT when grafts were used and when they wanted to have control over the alveolar inferior nerve canal. When there was more favorable bone availability the clinical evaluation was performed without CT.

- Model Studies in all cases was designed of complete and hybrid prosthesis like in immediate loading for partially fixed prosthesis, complete or hybrid.

- Surgery of models in cases with immediate loading of the partially fixed, complete or hybrid prosthesis.

- Surgical Ferule in those cases of immediate or differed loading, in $17.4 \%$ of the implants.

The objective of this study is to value the survival of the placed implants. When dealing with a study of 1,475 implants, $N$ global populations, placed according to different indicators and techniques we present a statistically exhaustive treatment that we go into more detail about later.

The first objective was to carry out the calculation to determine, from population $N$ of the total implants, the creation of dependent samples ( $n$ ) with a sufficient number of implants in each one, in order to obtain statistically valid results that are independent from the initial populations. All of this is intended to carry out independent survival studies of the different samples considered, immediate loading (ni) and post extraction (np). In order to do this we apply the following considerations (Pita 1995):

- To get the size of the sample we should define what the standard of error is going to be to get the variance and establish the fluctuation of $\exists$ (average value of the vari- 
paciente y el tipo de hueso según la clasificación de Leckholm y Zarb (1985). Con ello, determinamos, respecto a los mismos parámetros de la población $\mathrm{N}$, si el fracaso en estas subpoblaciones, ni y $\mathrm{np}$, es un factor aleatorio o está influenciado por alguno de estos parámetros.

\section{Resultados}

Se colocaron un total de 1.475 implantes en 480 pacientes con una edad media de 53,7 años (15-88 años), entre mayo del 2005 y junio del 2006, con un promedio de seguimiento cínico y radiológico, tras la carga de los mismos, de 2 años (de 19 a 29 meses).

El $80 \%$ de los pacientes presentaban una higiene oral buena o muy buena (Fig. 2) y solamente el $18 \%$ tenían enfermedad periodontal (Fig. 3). Predominaban claramente los huesos (según clasificación de Leckholm y Zarb, 1995) de tipo II (51\%) y III (26\%) (Fig. 4).

Se muestran las longitudes de los implantes empleadas en cada una de las posiciones dentales restauradas (Fig. 5), así como el diámetro de cada uno de ellos respecto a las posiciones dentales escogidas (Fig. 6). Asimismo, estas figuras muestran, en números absolutos, el detalle por longitudes y diámetros. La longitud más empleada fue la de $13 \mathrm{~mm},(40,5 \%)$, seguida de los de $15 \mathrm{~mm}(27 \%)$ y, en cuanto a diámetros, el más utilizado fue el de $3,4 \mathrm{~mm}$ $(36,3 \%)$, seguido de los de 3,75 y 4,25 (ambos un 31\%). Se observó el empleo mayoritario en cualquier posición de los implantes de diámetro más estrecho, incluso en regiones molares, siendo en el maxilar superior los de segunda elección después de los de diámetro de 4,25 mm.

Tras este seguimiento de 2 años de promedio, han fracasado 26 implantes en 24 pacientes, lo que supone un 1,8\% del total. Se analizaron tres variables en la subpoblación de implantes fracasados, que fueron la higiene oral de los pacientes, el tipo de hueso donde se colocaron y la presencia de enfermedad periodontal (Fig. 7). El análisis estadístico mediante la prueba de ANOVA, demuestra que ninguno de estos dos últimos parámetros es un factor dependiente o condicionante del fracaso de los implantes. Esta apreciación cambia notablemente cuando analizamos la higiene de estos pacien-

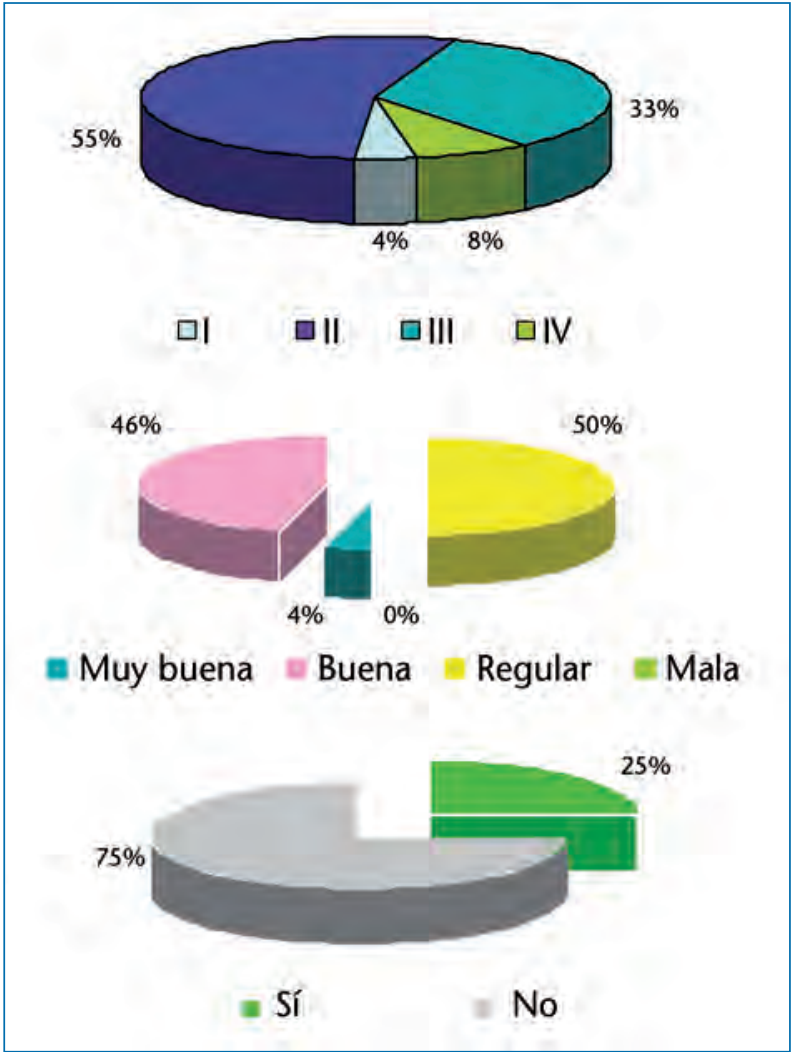

Figura 7. Variables analizadas en la subpoblación de implantes fracasados, tipo de hueso (arriba), higiene oral del paciente (medio) y presencia de enfermedad periodontal (debajo).

Figure 7. Variables analyzed in the subpopulation of failed implants, types of bone (up) oral hygiene of the patient (middle) and presence of periodontal disease (below).

Figura 8. Gráfica que detalla las causas de fracaso del total de los implantes.

Figure 8. Graph that details the cause of total implant failure. able) with respect to \# (average value of the same variable in population $\mathrm{N}$ ).

- On the other hand, once it has been established if we can create independent and representative subpopulations from the $N$ population of implants, we study the failure of those implants in each of them, using the normal analysis of the variance (ANOVA). Our questionnaire reports two comparative parameters factors: patient hygiene and the type of bone according to the Leckholm and Zarb classification (1985). With this we determine, regarding the same parameters of population $N$, if the failure is in these subpopulations(ni and ni) is a casual factor or if it is influenced by one of these parameters.

\section{Results}

A total of 1,475 implants were placed in 480 patients with an average age of 53.7 years (15-88 years) between may 2005 and june 2006, with an average clinical and radiological follow-up of 2 years (from 19 to 29 months).

$80 \%$ of patients had either good or very good oral hygiene (Fig. 2) and only 18\% had periodontal disease (Fig. 3). The bones were predominant (according to Leckholm and Zarb 1995) type II (51\%) and III (26\%) (Fig. 4).

The length of the implants used in each of the restored dental positions is shown (Fig. 5), for example the diameter of each one of them in regards to the dental positions chosen (Fig. 6). In like manner these figures show the detail of length and diameter in absolute numbers. The length used the most was $13 \mathrm{~mm}$, (40.5\%) followed by $15 \mathrm{~mm}$ (27\%). The most used diameter was $3.4 \mathrm{~mm}$ (36.3\%) followed by $3.75 \mathrm{~mm}$ and $4.25 \mathrm{~mm}$ (both 31\%).

Narrower diameters were used in the majority of cases in all positions, even in molar regions; they are the second 
tes (expresión porcentual respecto a número de implantes totales en cada paciente), ya que ANOVA sí rechaza la igualdad de estas medias. Nuestro estudio permite concluir que la higiene de los pacientes sí es un factor determinante en el fracaso de los implantes.

El $77 \%$ de los implantes fracasados lo hicieron por un fallo de la osteointegración, siendo la periimplantitis la causa en el $23 \%$ restante (Fig. 8). La distribución por huesos maxilares, destaca que 16 de los implantes fracasados estaban ubicados en el maxilar superior y 10 en la mandíbula. El análisis de los mismos por diámetros y con la valoración de su estabilidad primaria en el momento de la colocación por parte del implantólogo, se detalla en la Figura 9. A pesar de ser los de $3,4 \mathrm{~mm}$ de diámetro los más empleados, no son los que presentan un mayor fracaso de integración. Se han analizado otros factores es este estudio que se muestran independientes al fracaso de los implantes (Tabla 1).

Se diseñaron un total de 654 prótesis sobre implantes, con un promedio de prótesis/paciente de 1,4 y un promedio de implantes/prótesis de 2,2. El detalle del tipo de prótesis, tanto en números totales como porcentuales de muestra en la Figura 10, destacando que el $46 \%$ se trató de prótesis parciales fijas y el $36 \%$ de unitarias. Únicamente se relata un fracaso protésico, por fractura de un tornillo. La supervivencia protésica en este estudio fue del 99,8\%.

\section{Implantes postexodoncia}

A estos implantes los hemos denominado subpoblación $\mathrm{n}_{\mathrm{p}}$. El cálculo estadístico de la varianza y fluctuación de $\exists$ respecto a \# aplicado a partir del a población $\mathrm{N}$ de implantes totales, nos ha permitido concluir que la subpoblación $n_{p}$ es representativa de la población $\mathrm{N}$ y, por ello, podemos extraer una serie de resultados y conclusiones.

Se colocaron un total de 215 implantes postexodoncia $\left(n_{p}\right)$, que suponen un $14,6 \%$ del total, en 79 pacientes $(16,4 \%)$ de los pacientes del estudio y se diseñaron 83 prótesis $(12,7 \%$ del total) sobre estos implantes postexodoncia. El $67 \%$ se ubicaron en el maxilar superior y el $33 \%$ en la mandíbula. La Figura 11 muestra su distribución en ambos maxilares según las posiciones dentales.

Los diámetros elegidos con mayor frecuencia fueron los de 3,75 $\mathrm{mm}$ y $3,4 \mathrm{~mm}$ (Fig. 12). Se diseñaron principalmente prótesis parciales fijas y unitarias en la misma proporción (36\% ambas) (Fig. 13).

Fracasaron 7 implantes en estos 2 años de seguimiento, con una supervivencia global de la subpoblación $n_{p}$ del 96,8\%. Cua- option after $4.25 \mathrm{~mm}$ implants for superior maxilla implants.

After this average 2-year follow-up, 26 implants failed in 24 patients, which make up $1.8 \%$ of the total. The three variables of the subpopulation were analyzed which included patient hygiene, the type of bone where they were placed and the presence of periodontal disease (Fig. 7). The statistical analysis was performed using the ANOVA test, demonstrating that none of these two parameters is a dependent factor or conditional of failure of the implants. This changes notably when we analyze the hygiene of these patients (percentual expression with respect to the total number of implants in each patient), since ANOVA rejects the equality of these measures. Our study allows us to conclude that patients' hygiene is a determining factor in the failure of implants.

$77 \%$ of failed implants were caused by an error in Osseo integration, periimplantitis is the cause in the remaining 23\% (Fig. 8). The maxilla bone distribution reveals that 16 of the failed implants were located in the superior maxilla and 10 in the mandible. Analysis of the implants based on their diameters and the evaluation of their primary stability at the moment of placement by the implantologist is detailed in figure 9. Although implants with $3.4 \mathrm{~mm}$ diameter were the most often used, they are not the ones that have the most integration failure. Other factors have been analyzed it is this study that are showed independent from the failed implants (Table 1). 654 implant prosthesis' were designed, with an average prosthesis/patient ratio of 1.4 and an average implant/prosthesis ratio of 2.2. The detail of the prosthesis type in total numbers as well as in percentages is in Fig 10 , revealing that $46 \%$ were partially fixed prosthesis and $36 \%$ unitary. It is only related to prosthetic failure because of a screw fracture. The prosthetic survival in this study was $99.8 \%$.

\section{Post extraction implants}

These implants have been called subpopulation np. The statistical calculation of variance and fluctuation of \$ with 
tro fracasos acontecieron en el maxilar superior y 3 en la mandíbula, ocurriendo en todos los casos por un fallo de la osteointegración. La Figura 14 detalla el fracaso según los distintos diámetros, siendo el de los de 4,25 mm en $n_{p}$ es de 7,3\%; por otro lado el fracaso de los de $4,25 \mathrm{~mm}$ en el total de los implantes es de $1,5 \%$. Podría deducirse que el diámetro sí es un factor determinante en el fracaso de los implantes postexodoncia.

Se analizaron otros factores para determinar su implicación en el fracaso de los implantes postexodoncia $\left(n_{p}\right)$ : el tipo de hueso y la higiene de los pacientes (Fig. 15). Mediante la aplicación del parámetro estadístico ANOVA, se concluye que estos factores no son determinantes en el fracaso de los implantes postexodoncia.

\section{Implantes con carga inmediata}

Otra consideración especial hacemos en este estudio a los implantes con carga inmediata (Hourichi y cols., 2000; Malo y cols., 2003). Se considera carga inmediata aquellos implantes a los que se les ha aplicado la prótesis en las primeras 24-48 horas tras su colocación, según los criterios descritos en el World Congress Consensus Meeting de Barcelona en el año 2002 (Aparicio y cols., 2003; Cochran y cols., 2004).

Se aplicó carga inmediata a 58 implantes $\left(n_{i}\right)$ en nuestro estudio, el 3,9\% del total. Esta poca representatividad en cuanto a número global de la subpoblación ni hace que los resultados que obtengamos de esta subpoblación no serán avalados estadísticamente, por lo que nos limitaremos a expresar los resultados sin poder extraer conclusiones válidas de ellos; 41 de estos implantes (71\%) se colocaron en la mandíbula (Fig. 16). Todos los implantes superaban los 10 $\mathrm{mm}$ de longitud, predominando los de $13 \mathrm{~mm}$, (Fig. 17) y se emplearon, prácticamente en todos los casos, implantes de diámetros de $3,75 \mathrm{~mm}$ y $4,25 \mathrm{~mm}$ (Fig. 18).

Se diseñaron 32 prótesis de carga inmediata, el 50\% para prótesis parciales fijas, seguidas de las unitarias, con un $44 \%$. El resto fueron híbridas y completas mandi-

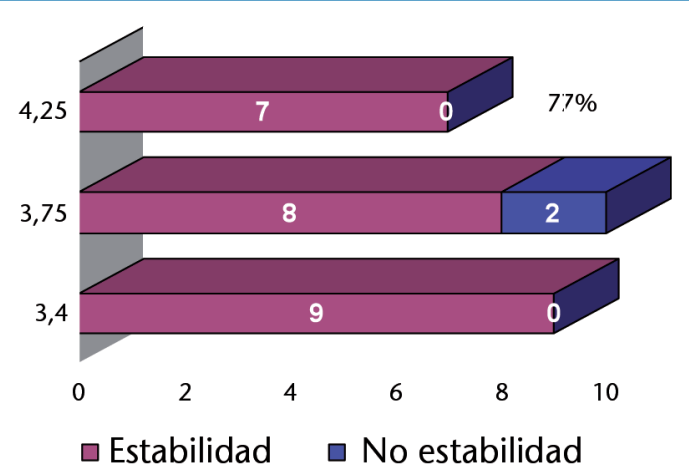

Figura 9. Detalle de los diámetros de los implantes fracasados, con especial mención a la consideración de la consecución de una estabilidad primaria en el momento de la colocación.

Figure 9. Detail of the diameters of the failed implants, with special mention to the consideration of the consecution of the first instability at the moment of placement.
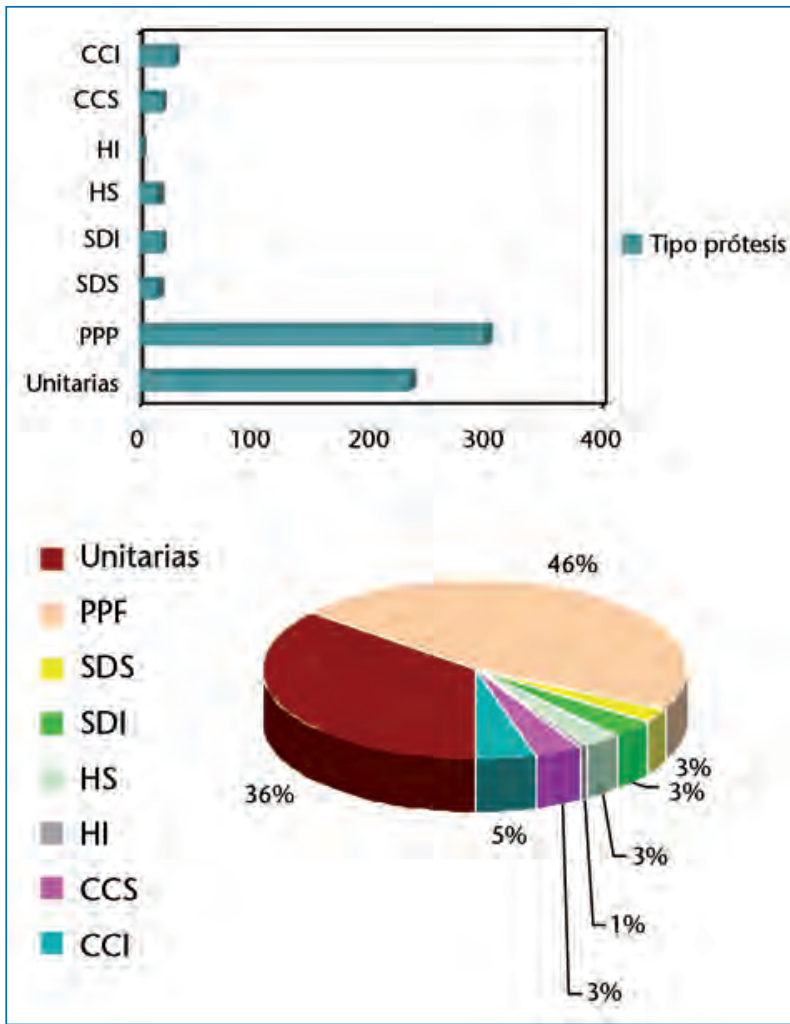

Figura 10. Detalle en números absolutos y en porcentaje de las prótesis diseñadas en el estudio. PPF- prótesis parcial fija (2 a 4); SDS-sobredentadura superior (4); SDI-sobredentadura inferior (2 a 4); HS-híbrida superior (5 a 6); HI-híbrida inferior (4); CCS-completa de coronas superior (6 a 10); CCl-completa de coronas inferior (4 all on four a 8).

Figure 10. Detail of absolute numbers and percentage of the prosthesis designed in this study... PPF-Partially Fixed Prosthesis (2 a 4); SDS-over superior denture (4); SDI-over inferior denture (2 a 4); HSsuperior hybrid (5 a 6); HI-inferior hybrid(4); CCS-complete superior crowns (6 a 10); CCl-complete inferior crowns (4 all on four a 8). respect to \# applied to population $N$, this has allowed us to we can extract a series of results and conclusions. A total of 215 post extraction implants (np) that make up $14.6 \%$ of the total, in 79 patients $(16.4 \%)$ of the patients in the study and 83 prosthesis were designed (12.7\% of the total) over those post extraction implants. $67 \%$ were placed in the superior maxilla and $33 \%$ in the mandible. The figure 11 shows the distribution in both maxillas according to their dental positions.

The diameters selected the most were $3.75 \mathrm{~mm}$ and 3.4 mm (Fig. 12). Mainly partially fixed and unitary prosthesis of the same proportion were designed both 36\%) (Fig. 3).

7 implants failed in the 2 years of follow up and the global survival rate of the $n p$ subpopulation was $96.8 \%$. Four failures happened in the superior maxilla and 3 in the mandible, they all happened because of failed Osseo integration. Figure 14 details the failure according to the distinct diameters, the percentage of failure for $4.25 \mathrm{~mm}$ in $n p$ is $7.3 \%$ and the percentage for all $4.25 \mathrm{~mm}$ diameter implants is $1.5 \%$. It can be deduced that the diameter is a determining factor in the failure of post extraction implants.

Other factors were analyzed to determine their implication in the failure of the post extraction implants $\left(n_{p}\right)$ : the type of bone and the hygiene of patients (Fig. 15). Using the application of the ANOVA statistical parameter we conclude that these factors are not determinant in the failure of post extraction implants. 
bulares (Fig. 19). El 97\% de las prótesis fueron cementadas.

Fracasó 1 implante de 4,25 por 13 $\mathrm{mm}\left(1,7 \%\right.$ respecto a $\left.n_{i}\right)$. Era un implante inmediato postexodoncia que presentaba dolor aunque sin movilidad en un paciente bruxista.9,10 La supervivencia de los implantes sometidos a carga inmediata en nuestra serie con un seguimiento de 2 años fue del 98,3\%.

\section{Injertos óseos}

Se colocaron 107 implantes $\left(n_{0}\right)$ (7,2\% del total) junto a algún procedimiento de injerto óseo en 55 pacientes $(11,5 \%$ del total). El injerto autólogo se empleó en el $76 \%$ de los casos (Fig. 20). El 61\% fueron injertos óseos onlay (Fig. 21). Dentro de los injertos óseos autólogos, el $82 \%$ eran particulados. En la figura 22 se detalla el origen y la zona donante de cada uno de ellos.

\section{Discusión}

De los resultados presentados en este estudio, nos parece interesante destacar dos aspectos fundamentales del mismo. Dado el tratamiento estadístico aplicado, obviaremos analizar el apartado de la carga inmediata, ya que, por el análisis de la varianza y fluctuación de nuestra subpoblación $\mathrm{n}_{\mathrm{i}}$, los resultados no son extrapolables ni reproducibles, y por ello, la alta supervivencia $(98,7 \%)$ a los 2 años no es significativa.

Analizaremos los implantes inmediatos postexodoncia y concretamente el elevado fracaso observado con los implantes de diámetro ancho $(4,25 \mathrm{~mm}$ y plataforma de $4,1 \mathrm{~mm}$ ) así como el empleo de implantes estrechos $(3,4 \mathrm{~mm}$ y plataforma estándar de 4,1 $\mathrm{mm}$ ) en cualquiera de las posiciones orales, ya que han sido los implantes más usados (36,3\% del total). No es fácil encontrar bibliografía reciente que analice el empleo de los implantes anchos inmediatos postexodoncia. Existe un estudio que demuestra que existe más reabsorción de hueso crestal en comparación al empleo de implantes con un diámetro estándar (Davarpanah, 2001).

Si analizamos los cambios morfológicos que acontecen en el lecho alveolar tras la exodoncia, veremos que la distancia horizontal o

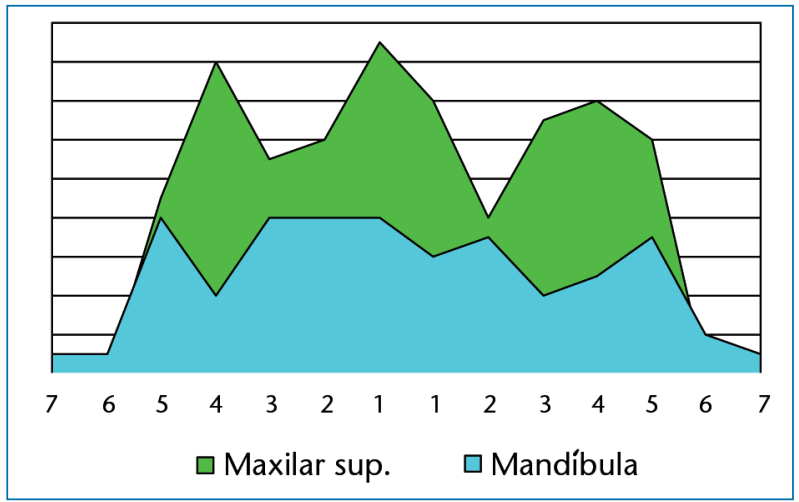

Figura 11. Distribución de los implantes postexodoncia entre los huesos maxilares (absoluta y porcentual), así como las posiciones en cada uno de los maxilares.

Figure 11. Distribution of post extraction implants between the maxiIla bones (absolute and percentage), like he positions of each one of the maxilla.

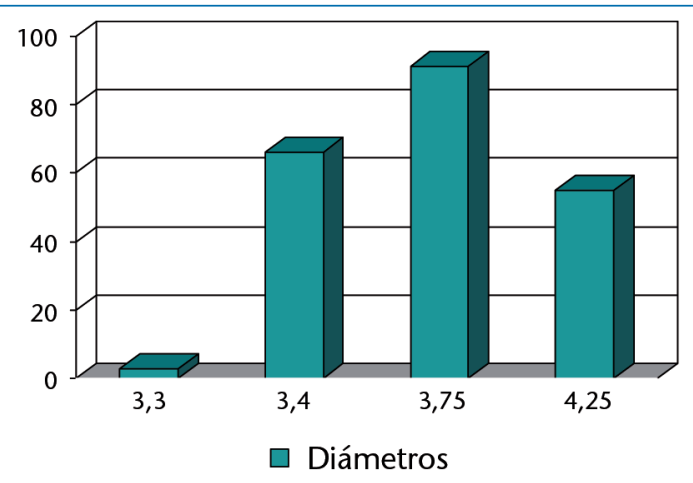

Figura 12. Detalle del diámetro de los implantes postexodoncia empleados.

Figure 12. Detail of the diameter of implants used after extraction.

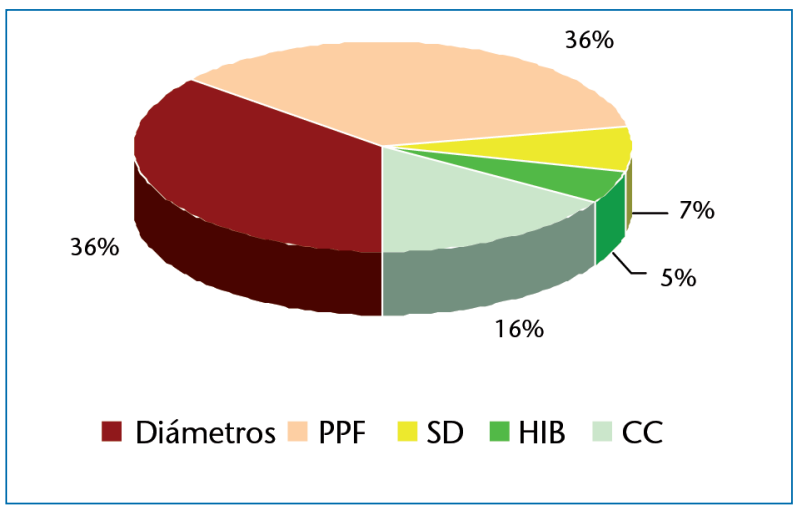

Figura 13. Prótesis realizadas sobre los implantes postexodoncia. Figure 13. Prosthesis carried out over the post extraction implants.
Implants that immediately load Another special consideration that we do in this study of immediate loading implants (Hourichi y cols. 2000: Malo and cols. 2003). Immediate loading implants are the ones that had prosthesis in the within 24-48 hours after their placement. This is according to the criteria described in the World Congress Consensus Meeting in Barcelona in 2002 (Aparicio and cols. 2003; Chochran and cols 2004). Immediate loading took place in 58 implants $\left(n_{i}\right)$ in our study, $3.9 \%$ of the total. This small representation in regards to the global number of the subpopulation ni means that the results we obtain of this subpopulation won't be statistically guaranteed which will limit our ability to express results without the power to draw valid conclusion from them. 41 of these implants (71\%) were placed in the mandible (Fig. 16). All the implants were longer than $10 \mathrm{~mm}$ in length prevailing the ones that are $13 \mathrm{~mm}$ (Fig. 17). In almost all of the cases implants 3.75 $\mathrm{mm}$ and $4.25 \mathrm{~mm}$ in diameter (Fig. 18) were used.

32 prosthesis of immediate loading were designed, 50\% of which were for partially fixed prosthesis and $44 \%$ for unitary. The rest were hybrid and complete mandible (Fig. 19). $97 \%$ of the prosthesis was cemented.

One implant failed that was 4.25 by $13 \mathrm{~mm}(1.7 \%$ respect to ni). It was an immediate post extraction, there was pain although there was no movement in patients with bruxism.9,10 Survival of the implants subjected to immediate loading in our series of follow up of 2 years was $98.3 \%$.

107 implants $\left(n_{0}\right)$ (7.2\% of the total) along with a bone graft procedure in 55 patients $(11.5 \%$ of the total) the autol- 


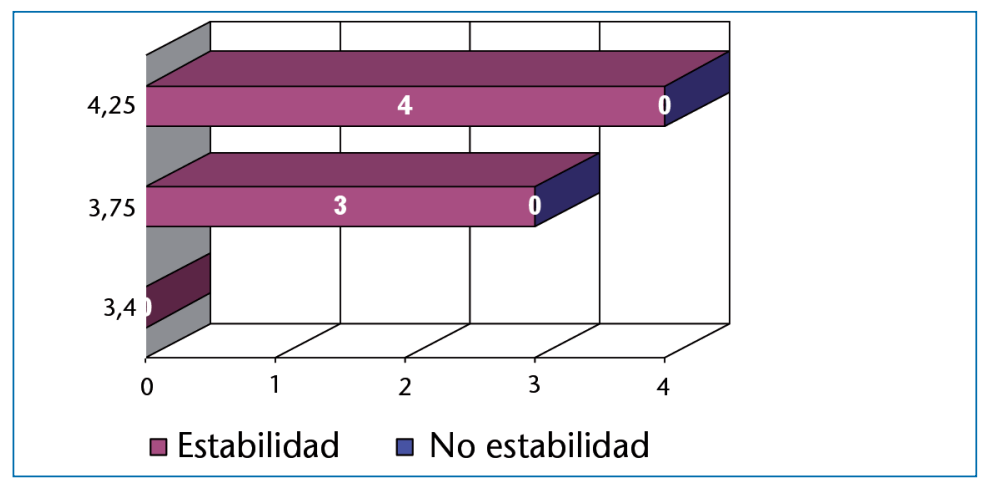

Figura 14. Detalle de los implantes postexodoncia fracasados según el diámetro.

Figure 14. Detail of the failed post extraction implants according to their diameter.

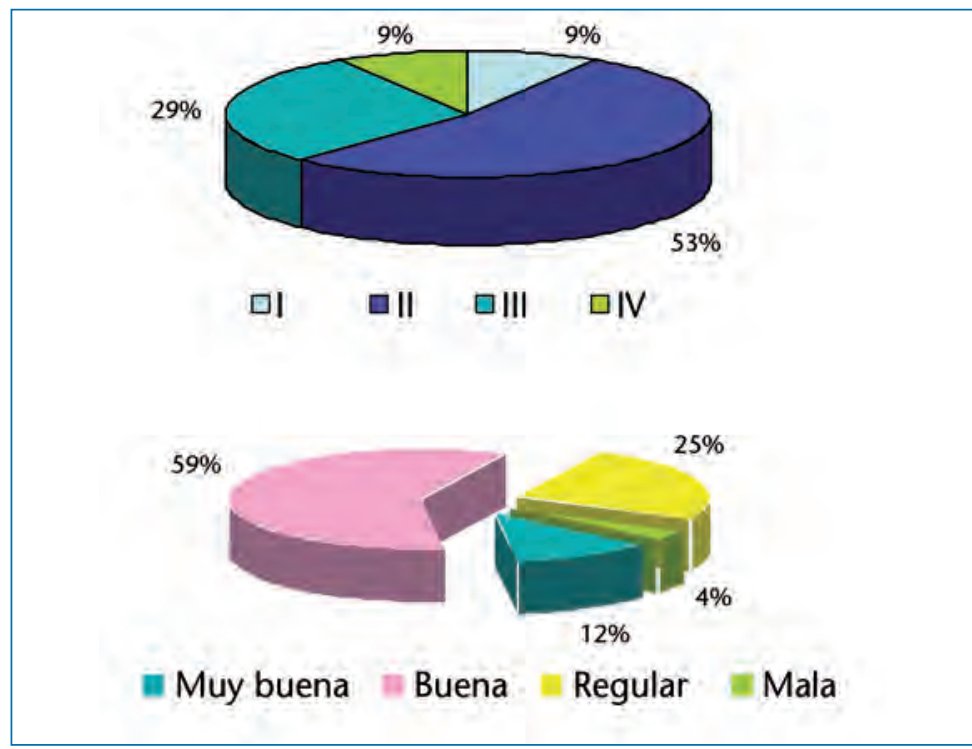

Figura 15. Parámetros estudiados para determinar su implicación en el fracaso de los implantes postexodoncia: tipo de hueso (arriba) e higiene de los pacientes (debajo).

Figure 15. Parameters studied to determine the implications of bone type (up) and patient hygiene (down) in post extraction implants.

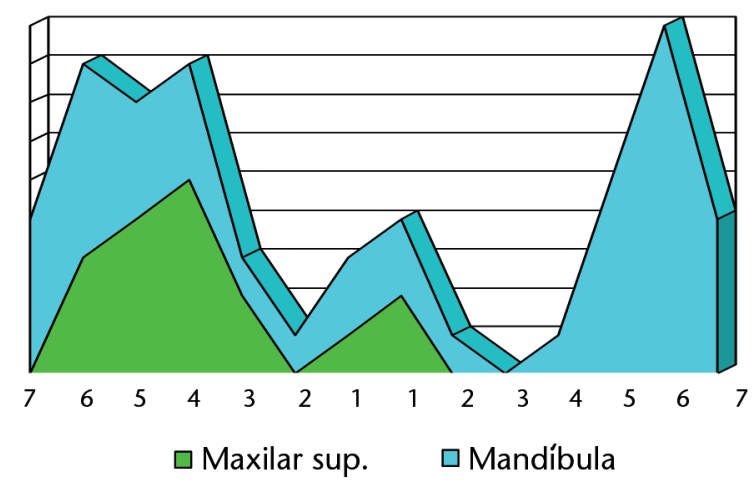

Figura 16. Distribución por maxilares y posiciones dentales de los implantes colocados y sometidos a carga inmediata.

Figure 16. Distribution by maxillaries y posiciones dentales de los implantes colocados y sometidos a carga inmediata.

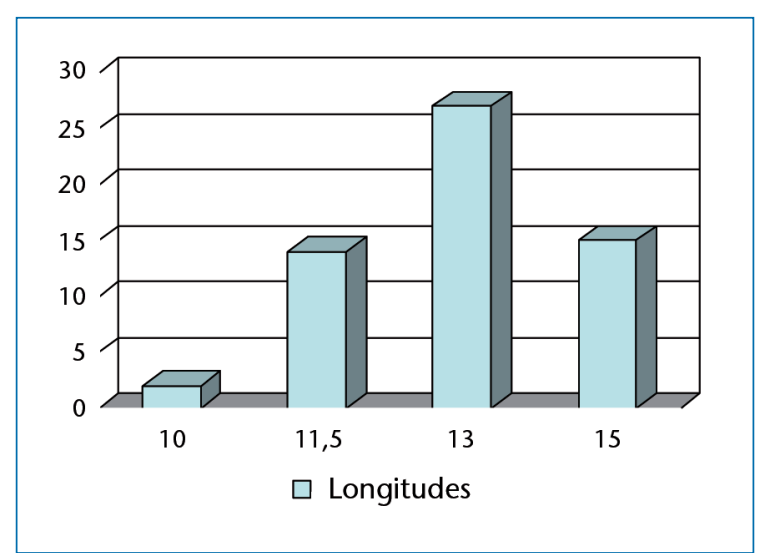

Figura 17. Longitudes de implantes (en $\mathrm{mm}$ ) empleadas para carga inmediata.

Figure 17. Length of immediately loaded implants (in $\mathrm{mm}$ ).

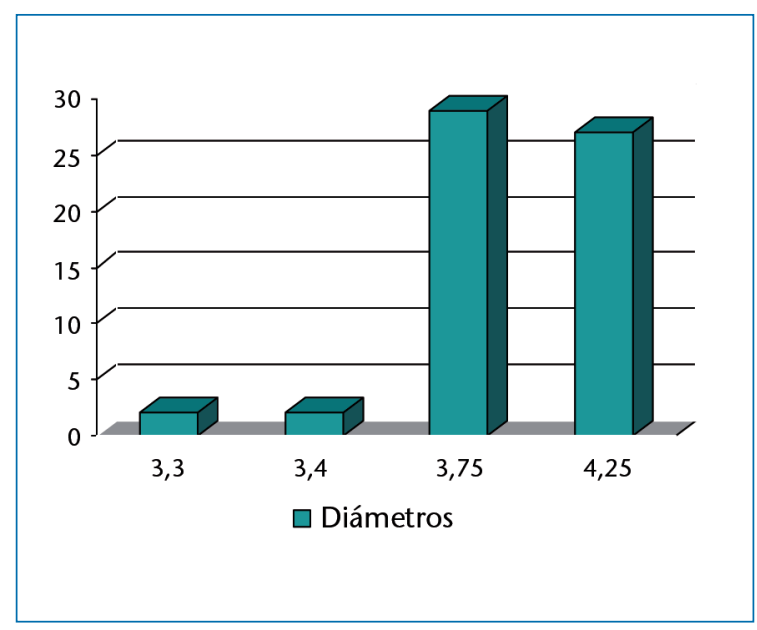

Figura 18. Diámetros de los implantes (en $\mathrm{mm}$ ) empleados para carga inmediata.

Figure 18. Diameter of implants used for immediate loading (in $\mathrm{mm})$.

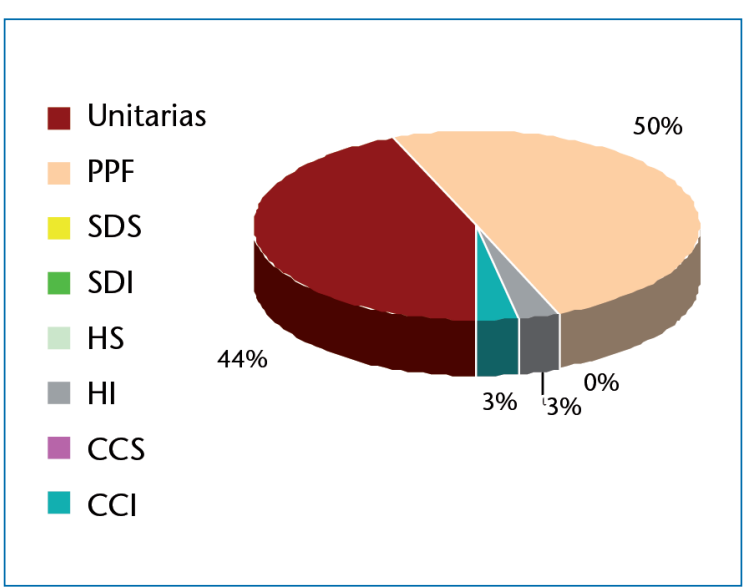

Figura 19. Distribución porcentual de las prótesis diseñadas para carga inmediata (ver Fig. 10).

Figure 19. Percentage distribution of the prosthesis designed for immediate loading (sea Fig. 10). 
anchura vestíbulo-lingual se reduce entre 5-7 mm en un periodo de 6-12 meses, lo que representa casi el $50 \%$ de la anchura alveolar inicial. La mayoría de estos cambios tienen lugar durante los 4 primeros meses de cicatrización (Lam, 1960). Estos datos biológicos sugieren unas recomendaciones quirúrgicas a la hora de realizar una exodoncia previa a la colocación de un implante inmediato, como son la máxima preservación de las paredes alveolares, sobre todo la vestibular en el maxilar superior y la lingual en la mandíbula (Peñarrocha y cols., 2004). Cuando se coloca un implante en un lecho postexodoncia, se busca la estabilidad primaria, tanto fresando entre 3 y $5 \mathrm{~mm}$, como mínimo, por encima del ápice del lecho alveolar, como empleando implantes de un diámetro ligeramente más ancho que el proceso alveolar remanente (Becker y Becker, 1996). Si se emplean implantes de diámetro ancho para disminuir la distancia entre el hueso y la superficie implantaria, junto al debilitamiento de las paredes alveolares tras la exodoncia, parece que existe una mayor probabilidad de reabsorción ósea por compresión de una pared alveolar débil cuando se emplea un implante de diámetro ancho. Esta podría ser una razón del elevado índice de fracaso proporcional de implantes más anchos en inmediatos postexodoncia. Por ello, podría ser conveniente conseguir una estabilidad primaria de los implantes postexodoncia mediante un fresado más apical al lecho alveolar, en lugar de comprimiendo las paredes alveolares con implantes de diámetro más ancho.

Muchos autores abogan por dejar una discreta discrepancia (menor a 1,5 $\mathrm{mm}$ ) entre la superficie del implante y las paredes alveolares, recurriendo a técnicas de regeneración ósea guiada para llenar este espacio. Autores como Brugnami y cols., 1996 o Dealemans y cols., 1997 recomiendan el empleo de injertos óseos autólogos para mejorar la capacidad osteoinductiva. Otros autores (Moscovitch, 2001), proponen y defienden el uso de dos implantes de menores diámetros (principalmente 3,5 mm) para la restauración de lechos alveolares postexodoncia en zonas molares, evitando compresiones de las paredes óseas y empleando técnicas de regeneración ósea.

A pesar de ello, la supervivencia del $96,8 \%$ en estos 2 años de seguimiento en estos implantes, se similar a los resultados del meta-

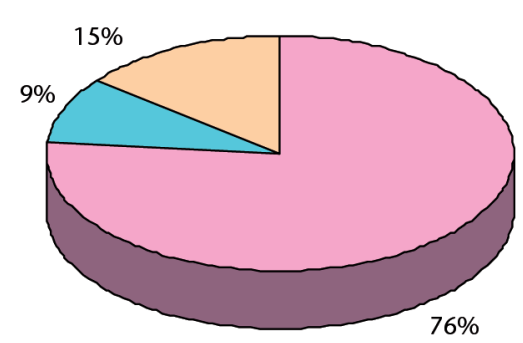

$\square$ Autólogo $\square$ Aut+Biomaterial $\square$ Biomaterial

Figura 20. Distribución del tipo de injertos empleados en el estudio.

Figure 20. Distribution of grafts used in this study.
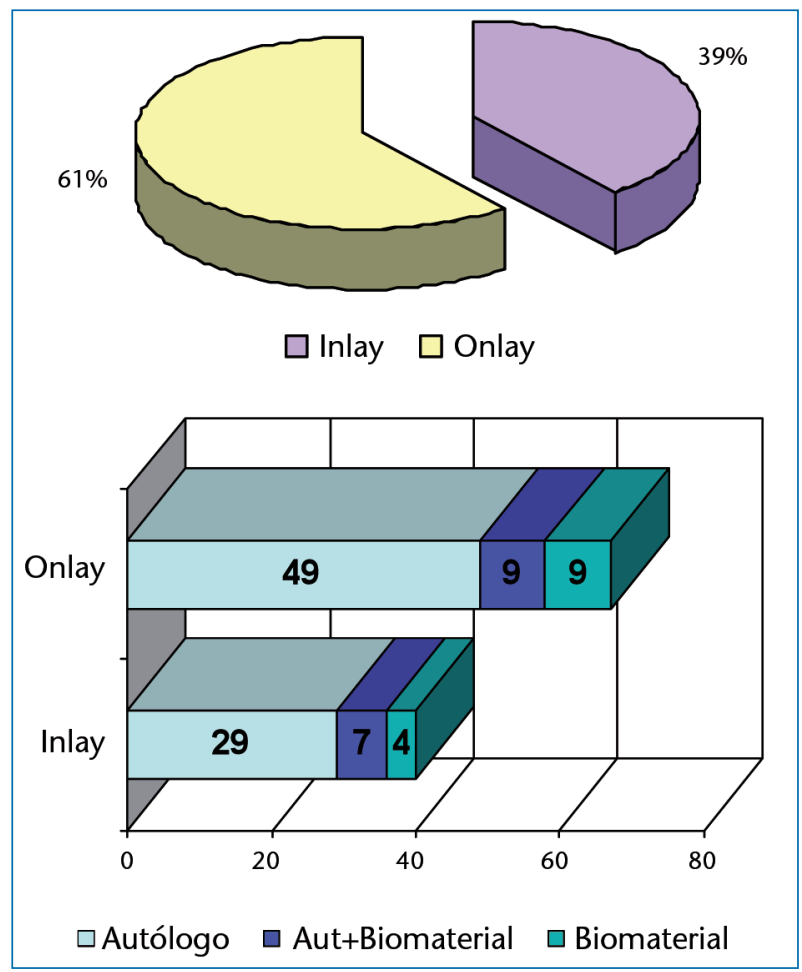

Figura 21. Distribución inlay/onlay de los injertos óseos del estudio (arriba). Gráfico de subdivisión según los materiales empleados en números absolutos de procedimientos (debajo). Graphic subdivision according to the materials used in numbers absolute to the procedures (down).

\section{Discussion}

Out of the results presented in this study, it is interesting to discuss two fundamental aspects. Given the statistical treatment applied, it is obvious we need to analyze the box of immediate loading since, because of the analysis of the variance and fluctuation of the ni subpopulation; the results are not extrapolated or reproducible. As a result a high survival rate (98.7\%) after two years is not significant.

We analyze immediate post extraction implants, specifically the high failure rate seen in wide diameter implants $(4.25 \mathrm{~mm}$ and $4.1 \mathrm{~mm}$ platform). So the use of narrow implants (3.4 mm and standard $4.1 \mathrm{~mm}$ platform) in any of the oral positions, since they have been the most used implants (36.3\% of the total).

It is not easy to find a recent biography that analyzes the use of wide immediate post extraction implants. There is one study that demonstrates that there is more crestal bone reabsorbing compared to the use of implants with a standard diameter (Davarpanah, 2001).

If we analyze the morphological changes that happen in the alveolar bed after extraction, we will see that the horizontal distance and width of the lingual vestibule reduces between 5-7 mm in a period of 6-12 months. This represents almost $50 \%$ of the initial alveolar width. The majority of these changes take place during the first 4 months of scarring (Lam 1960). These biological data suggest surgical recommendations when carrying out extraction prior to plac- 
análisis de Chen y cols. en 2004 en una revisión de 18 estudios, que sitúan la supervivencia entre el $89,9 \%$ y el $100 \%$.

El otro interesante de analizar es el elevado porcentaje (36,3\% del total) de implantes de diámetro de 3,4 mm (estrechos) empleados en cualquier posición oral, incluso en restauraciones de molares (principalmente de los primeros molares) en ambos maxilares. Los implantes estrechos fueron comercialmente introducidos en la década de los 90 , empleados inicialmente como implantes transicionales (Petrungaro y Windmiller 2001; Brown y Tarnow 2001). Hoy en día se utilizan de una forma más generalizada para cualquier tipo de rehabilitación. Diversos estudios han demostrado que se integran de la misma manera que los de diámetro estándar y se han publicado resultados con un seguimiento entre 6 y 27 meses, que oscilan entre el $93 \%$ y el $98 \%$ de supervivencia (English y Bohle, 2003; Froum y cols., 2005; Cho y cols., 2007; Labarre y cols., 2008). Un estudio sobre 2.514 de estos implantes a los 5 años (Shatkin y cols., 2007), reporta una tasa de supervivencia del $94,2 \%$.

Los resultados en el presente estudio de supervivencia de estos implantes de 3,4 mm de diámetro (535 colocados, 9 fracasos con un $98,3 \%$ de supervivencia a los 2 años) son muy aceptables. Analizando las altas tasas de supervivencia de estos implantes publicados en la literatura, parece que su empleo es muy útil y garantiza tan buenos o mejores resultados, en cualquier posición de la boca, que los implantes de diámetro estándar de 3,75 mm (451 colocados, 10 fracasos, con un $97,8 \%$ de supervivencia a los 2 años).

El presente estudio con los implantes MG-OSSEOUS puede ser comparado con otros estudios publicados en la literatura, como los que se reflejan en la tabla 2 .

\section{Conclusiones}

Un buen protocolo de estudio, personalizado para cada una de las indicaciones, asegura unos buenos resultados finales. Se pueden emplear implantes de diámetro estrecho $(3,4 \mathrm{~mm})$ en cualquier posición oral, incluida la zona molar, principalmente en el maxilar superior, con una supervivencia a los 2 años similar a los estándar. La higiene oral de los pacientes es un factor que parece condicionar el fracaso de los implantes aunque parece no ser un factor determinante de fracaso en los implantes inmediatos postexodoncia. El empleo de implantes de diámetro ancho $(4,25 \mathrm{~mm})$ en casos postexodoncia podría ser factor de riesgo que para el fracaso. ing an immediate implant. They are the maximum preservation of the alveolar walls especially the vestibular in the superior maxilla and the lingual of the mandible (Peñarrocha and cols. 2004). When an implant is placed in the floor after extraction we look for primary stability when drilling between 3 and $5 \mathrm{~mm}$ minimum above the apex of the alveolar bed, like using implants with a diameter that is slightly wider than the remaining alveolar process (Becker and Becker 1996). If implants with a wide diameter are used to decrease the distance between the bone and the implant surface, along with weakening the alveolar walls after extraction it seems that there is a greater possibility of bone reabsorbing by compression of a weak alveolar wall when a wide diameter implant is used. This could be the cause of the elevated failure index proportional to wider implants in immediate post extraction. Because of this it could be convenient to establish primary stability of the post extraction implants using a more apical drill for the alveolar bed in stead of compromising the alveolar walls with implants that are wider in diameter.

Many authors are in favor of discrete discrepancy between the surface of the implant and the alveolar walls, resorting to regenerative bone techniques intended to fill this space. Authors like Brugnami and cols, 1996 or Dealemans and cols 1997 recommend the use of autologous bone grafts to improve the bone inductive capacity. Other authors (Moscovitch 2001) propose and defend the use of 2 implants with smaller diameters for the restoration of post extraction alveolar bed in molar zones, avoiding compression of bone walls and using bone regenerative techniques.

Despite this, the $96.8 \%$ survival rate in the 2 year follow-up of these implants is similar to the results of Meta analysis by Chen and cols in 2004 when reviewing 18 studies that put survival between $89.9 \%$ and $100 \%$.

It is also interesting to analyze the increased percentage of implants with a $3.4 \mathrm{~mm}$ diameter (narrow) used in any oral position, including restoring molars (mainly in first molars) in both maxillas. The narrow implants were commercially introduced in the 90's, initially used as transitional implants (Petrungaro and Windmiller 2001; Brown Tarnow 2001). 


\section{Agradecimientos}

A los Dres. Juan Luis Alonso de Dios, Luis Antonio Hernandez Martin, Luis Naval Gías, Carlos Orduña Domingo, Salvador Ortuño Laguia, Juan Jose Rodriguez Ortega, Angel Sancho Garcia, Fermin Terron Miron y Marcos Terron Gonzalez, por su participación desinteresada en este estudio.

\section{Bibliografía}

1. Albrektsson $T$, Wennerberg A. The impact of oral implants-past and future, 1966-2042. / Canad Dent Ass 2005;71:327.

2. Aparicio C, Rangert B, Sennerby L. Immediate/early loading of dental implants: a report form the Sociedad Española de Implantes World Congress Consensus Meeting in Barcelona, Spain. Clin Impl Dent Rel Res 2002;5:57-60.

3. Barajas Pinzón OM. Breve Historia de la Ingeniería Mecánica. Parte I. Ingenierias 2003;19:4753.

4. Becker W, Becker BE. Flap designs for minimization of recession adjacent to maxillary anterior implant sites. A clinical study. Inter J Oral Maxillofac Impl 1996;11:46-54.

5. Brown M, Tarnow D. Fixed provisionalization with transtional implants for partially edentulous patients: a case study. Pract Procc Aesth Dent 2001;13:123-127.

6. Brugnami F, Then P, Moproi H. Histological evaluation of human extraction sockets treated with demineralized freeze-dried bone allograft and cell occlusive membrane. J Periodontol 1996;67:821825.

7. Chen ST, Wilson TG, Hämmerle CHF. Immediate or early placement of implants following tooth extraction: review of biologic bases, clinical procedures and outcomes. Int Jo Oral Maxillofac Impl 2004;19(suppl): 12-25.

Tabla 2. Otros estudios comparativos

\begin{tabular}{|c|c|c|c|c|c|c|}
\hline $\begin{array}{l}\text { Autor } \\
\text { (n' ret.) } \\
\text { sistema de } \\
\text { implante } \\
\end{array}$ & Indicacion & $\begin{array}{l}\text { Pacientes/implantes } \\
\text { segulmlento } \\
\text { tasa de exito } \\
\text { Acumulato (TEA) } \\
\text { inplantes } \\
\text { Supervivientes (15) }\end{array}$ & $\begin{array}{l}\text { Cinterios de } \\
\text { inclussion }\end{array}$ & $\begin{array}{l}\text { metoso parn } \\
\text { increinentar ia } \\
\text { estabilitad } \\
\text { inicial o decidir } \\
\text { que implantes } \\
\text { cargar }\end{array}$ & $\begin{array}{l}\text { Factores } \\
\text { considerados } \\
\text { para } \\
\text { Influenciar } \\
\text { el resultado }\end{array}$ & Comentarios \\
\hline $\begin{array}{l}\text { Schitman }{ }^{4} \\
\text { BS }\end{array}$ & $\begin{array}{l}\text { Mandioulas } \\
\text { completas } \\
\text { Puente fijo }\end{array}$ & $\begin{array}{l}10 / 28 \\
8.10 \text { años } \\
4 \text { pérdidas } \\
\text { TEA } 85.7 \%\end{array}$ & $\begin{array}{l}\text { Anciaje bicortical } \\
\text { en un hueso } \\
\text { denso } \\
\text { Estabilidad } \\
\text { primaria }\end{array}$ & $\begin{array}{l}\text { Técnica quirúrgica } \\
\text { modificada isin } \\
\text { terraja o } \\
\text { terraja corta) }\end{array}$ & $\begin{array}{l}\text { Ferulizacion para } \\
\text { evitar micromo- } \\
\text { vimientos Calidad } \\
\text { de hueso, y ajuste } \\
\text { inicial. Estabilidad } \\
\text { frente a la longitud } \\
\text { del implante }\end{array}$ & $\begin{array}{l}\text { Se colocan } \\
\text { implantes } \\
\text { extra de } \\
\text { rescate }\end{array}$ \\
\hline $\begin{array}{l}\text { Jarnow" } \\
\text { BS, in } \\
\text { Astra, } 31\end{array}$ & $\begin{array}{l}\text { Mandibulas y } \\
\text { y maxilanes } \\
\text { superiores } \\
\text { completos } \\
\text { Puente fijo }\end{array}$ & $\begin{array}{l}10 / 69 \\
1.5 \text { anos } \\
2 \text { perdidas } \\
\text { Resultados is } \\
97,4 \%\end{array}$ & $210 \mathrm{~mm}$ & Penotest & $\begin{array}{l}\text { Arcos sin dientes } \\
\text { que crean estab|- } \\
\text { lidad de herradu. } \\
\text { ras de metal } \\
\text { rigido. Longitud } \\
\text { ininima del im. } \\
\text { plante ( } 10 \text { mm) } \\
\text { Distribución de } \\
\text { implantes }\end{array}$ & $\begin{array}{l}\text { Se colocan } \\
\text { impiantes } \\
\text { extra de } \\
\text { rescate Al } \\
\text { menos } 10 \\
\text { implantes } \\
\text { por } \\
\text { mancioula }\end{array}$ \\
\hline $\begin{array}{l}\text { Ealsh" } \\
\text { BS }\end{array}$ & $\begin{array}{l}\text { Mandibulas } \\
\text { completas } \\
\text { Puente fijo }\end{array}$ & $\begin{array}{l}10 / 40 \\
\text { no especificado } \\
8 \text { pérdidas } \\
\text { Resultado } 1580 \% \\
\text { en la conexión } \\
\text { de pilares }\end{array}$ & $\begin{array}{l}\text { Selección de } \\
\text { pacientes } \\
\text { inclurendo } \\
\text { parafunción. } \\
\text { tabaquismo y } \\
\text { calidad poore } \\
\text { de hueso }\end{array}$ & $\begin{array}{l}\text { Distribución } \\
\text { de implantes }\end{array}$ & $\begin{array}{l}\text { Callidad de hueso } \\
\text { Selección } \\
\text { de paciente }\end{array}$ & $\begin{array}{l}\text { Se colocaron } \\
10 \text { implantes } \\
\text { de los cuales } \\
4 \text { fueron } \\
\text { cargados in. } \\
\text { mediatemente }\end{array}$ \\
\hline $\begin{array}{l}\text { Chiapasco" } \\
\text { TPS, IT. } \\
\text { HA }\end{array}$ & $\begin{array}{l}\text { Mandloulas } \\
\text { completas } \\
\text { Sobreden- } \\
\text { tadura }\end{array}$ & $\begin{array}{l}194 / 776 \\
2.13 \text { años } \\
24 \text { peraidas } \\
\text { Resultado is } \\
96,9 \%\end{array}$ & $\begin{array}{l}210 \mathrm{~mm} \\
\text { ningün } \\
\text { onuxómano }\end{array}$ & $\begin{array}{l}\text { De acuerdo con } \\
\text { procedimientos } \\
\text { estinndar }\end{array}$ & $\begin{array}{l}\text { Estabilidad primara } \\
\text { Ningün movimiento }\end{array}$ & $\begin{array}{l}\text { Retrospectivo } \\
\text { Recomienda } \\
4 \mathrm{~mm} \text { dametro } \\
\text { y } 14 \text { mm de ion. } \\
\text { gitud. De otro } \\
\text { modo 2.fases }\end{array}$ \\
\hline $\begin{array}{l}\text { Brdànemark' } \\
\text { BS }\end{array}$ & $\begin{array}{l}\text { Mandibulas } \\
\text { completas } \\
\text { Puente flo }\end{array}$ & $\begin{array}{l}50 / 150 \\
1 \text { año } \\
3 \text { perdidas } \\
\text { Resultados is } \\
98 \%\end{array}$ & $13 \mathrm{~mm}$ & $\begin{array}{l}\text { La técnica } \\
\text { quirúrgica } \\
\text { requerida } \\
\text { por el } \\
\text { concepto }\end{array}$ & $\begin{array}{l}\text { El calor excesivo } \\
\text { en el hueso es } \\
\text { una de las razones } \\
\text { posibles } \\
\text { de fracaso }\end{array}$ & $\begin{array}{l}\text { Concepto } \\
\text { minimizado, } 3 \\
\text { implantes/man- } \\
\text { dibula }\end{array}$ \\
\hline $\begin{array}{l}\text { Ericsson \& } \\
\text { Randow } \\
\text { BS }\end{array}$ & $\begin{array}{l}\text { Mandiouias } \\
\text { completas } \\
\text { Puente fio }\end{array}$ & $\begin{array}{l}16 / 88 \\
1.5 \text { años } \\
13 / 72 \\
\text { S sños } \\
\text { CSR } 100 \%\end{array}$ & $\begin{array}{l}5.6 \text { implantes } \\
\text { anclaje bicortical } \\
\text { > } 10 \mathrm{~mm}\end{array}$ & $\begin{array}{l}\text { De acuerdo } \\
\text { con los } \\
\text { procedimientos } \\
\text { estandar }\end{array}$ & $\begin{array}{l}\text { La posición del } \\
\text { implante en la } \\
\text { mandibula y su } \\
\text { estabilidad inicial. } \\
\text { Longitud del im- } \\
\text { plante Bruxomano } \\
\text { o no }\end{array}$ & $\begin{array}{l}\text { Cangado en las } \\
3 \text { semanas des- } \\
\text { pués de la colo- } \\
\text { cacion. Perdida } \\
\text { de hueso com- } \\
\text { parable al proce. } \\
\text { dimieneto en } \\
2 \text { estadios }\end{array}$ \\
\hline $\begin{array}{l}\text { Catti } \\
\text { ITI (TPS) }\end{array}$ & $\begin{array}{l}\text { Mandibulas } \\
\text { completas } \\
\text { Sobreden- } \\
\text { tadura }\end{array}$ & $\begin{array}{l}21 / 84 \\
2.5 \text { arios } \\
0 \text { perdidas } \\
\text { TEA } 96.0 \%\end{array}$ & $\begin{array}{l}4 \text { implantes/pa. } \\
\text { clentes }>10 \mathrm{~mm} \\
\text { Ningún bruxista } \\
\text { severo. No histo. } \\
\text { ria de peraldas }\end{array}$ & $\begin{array}{l}\text { De acuerdo con } \\
\text { procedimientos } \\
\text { estandar }\end{array}$ & $\begin{array}{l}\text { Número de im. } \\
\text { plantes colocados. } \\
\text { su distribucion } \\
\text { y tipo de conezion } \\
\text { rigida }\end{array}$ & $\begin{array}{l}\text { La baja TEA se } \\
\text { debio a la } \\
\text { reabsorcion } \\
\text { osea }\end{array}$ \\
\hline $\begin{array}{l}\text { Womle" } \\
\text { StenOss } \\
\text { TPS,HA1 }\end{array}$ & $\begin{array}{l}\text { Unitarios } \\
\text { Incisivos } \\
\text { dei maxilat } \\
\text { superior }\end{array}$ & $\begin{array}{l}14 / 14 \\
9.36 \text { meses } \\
\text { Resultadoo ISI } \\
100 \%\end{array}$ & $\begin{array}{l}45 \mathrm{~N} / \mathrm{cm} \text { de fuer. } \\
\text { za de inserción, } \\
\text { cantidao de hueso } \\
\text { A, B Selección de } \\
\text { paciente. No se } \\
\text { levanta ningün } \\
\text { colgajo }\end{array}$ & $\begin{array}{l}\text { Pensado para } \\
\text { emplear la lamina } \\
\text { dura de airededor } \\
\text { del hueso alveolar } \\
\text { para la obtención } \\
\text { de estabilidad } \\
\text { iniclal }\end{array}$ & $\begin{array}{l}\text { Ajuste del innplante } \\
\text { en el lugar de la ex. } \\
\text { traccion. Ato torque } \\
\text { de insercion. Mante. } \\
\text { nimiento de la esta. } \\
\text { bilidad primana, los } \\
\text { micromovimientos } \\
\text { se evitan }\end{array}$ & $\begin{array}{l}\text { Todos los } \\
\text { implantes se } \\
\text { colocaron en } \\
\text { alveolos de } \\
\text { extraccion }\end{array}$ \\
\hline $\begin{array}{l}\text { Encsson } \\
\text { BS }\end{array}$ & $\begin{array}{l}\text { Unitarios } \\
\text { Maxilar sup. } 11 \\
\text { Mandibula } 3\end{array}$ & $\begin{array}{l}14 / 14 \\
18 \text { meses } \\
2 \text { perdidas } \\
\text { Resuitado } 151 \\
85.7 \% \\
(81.8 \%, 100 \%)\end{array}$ & $\begin{array}{l}\text { ₹ } 13 \mathrm{~mm} \\
\text { ningun/minimo } \\
\text { contacto oclusal } \\
\text { ningún molar } \\
\text { no oruxornanos } \\
\text { ningùn fumador }\end{array}$ & $\begin{array}{l}\text { De acuerdo a } \\
\text { procedimientos } \\
\text { estandar }\end{array}$ & $\begin{array}{l}\text { Estabilidad inicial } \\
\text { Apoyo oclusal de } \\
\text { tocio el arco. Ausen- } \\
\text { cia de una carga } \\
\text { completa } \\
\text { incontrolada }\end{array}$ & $\begin{array}{l}\text { Percida de } \\
\text { hueso } \\
\text { comparable al } \\
\text { procedimiento } \\
\text { en } 2 \text { fases }\end{array}$ \\
\hline $\begin{array}{l}\text { Malo } \\
\text { Bs: }\end{array}$ & $\begin{array}{l}\text { Unitarios/ } \\
\text { parciales } \\
\text { Zona estetica } \\
\text { Maxilar sup } 57 \\
\text { Mandioulas } 37\end{array}$ & $\begin{array}{l}49 / 94 \\
1.2 \text { anlos } \\
4 \text { perdidas } \\
\text { TEA } 95.7 \% \\
194,7 \%, 97,3 \% 1\end{array}$ & $\begin{array}{l}\text { Min } 32 \text { N/cm de } \\
\text { fuerza de inser- } \\
\text { cion z } 10 \mathrm{~mm} \\
\text { Ningün contacto } \\
\text { oclusal Ningún } \\
\text { injerto. Ningún } \\
\text { bruxomano }\end{array}$ & $\begin{array}{l}\text { Técnica quinurgica } \\
\text { modificada para } \\
\text { optimizar el apor. } \\
\text { te de sangre (sin } \\
\text { despegamiento } \\
\text { muco penóstico) } \\
\text { y conseguir com. } \\
\text { presión osea imas } \\
\text { de } 70 \mathrm{~N} / \mathrm{cm} \text { de } \\
\text { insercion) }\end{array}$ & $\begin{array}{l}\text { Anciaje del } \\
\text { impiante primaria } \\
\text { y stuación de } \\
\text { carga controlada }\end{array}$ & $\begin{array}{l}\text { Retrospectivo } \\
\text { Las perdidas } \\
\text { fueron en aweo. } \\
\text { lo-extraccion. } \\
\text { Hueso cicatn. } \\
\text { zado } 100 \text { s } 15 \\
\text { Peraida osea de } \\
0.8 \text { mm desde } \\
\text { la insercón nasta } \\
1 \text { año de seguil. } \\
\text { miento }\end{array}$ \\
\hline $\begin{array}{l}\text { Clasuser } \\
\text { BS }\end{array}$ & $\begin{array}{l}\text { Todos tia } \\
\text { mavoria uni- } \\
\text { tarios/parcial } \\
\text { Maxilar sup } 75 \\
\text { Mandibula } 52\end{array}$ & $\begin{array}{l}41 / 127 \\
6 \text { meses } \\
18 \text { perdidas } \\
\text { TEA } 85,8 \% \\
180.3 \%, 94.1 \%\end{array}$ & $\begin{array}{l}\text { Estabisidad inicial } \\
\text { suficiente. } \\
\text { Pacientes nor- } \\
\text { maies, incluven } \\
\text { procedimientos } \\
\text { locales de RTC }\end{array}$ & $\begin{array}{l}\text { Mkiv + } \\
\text { modificacion de } \\
\text { la tecnica } \\
\text { quirügica }\end{array}$ & $\begin{array}{l}\text { Calidad osea } \\
\text { pobre/poca can } \\
\text { tidad de hueso/ } \\
\text { cargas excesivas, } \\
\text { son factores } \\
\text { de riesgo }\end{array}$ & $\begin{array}{l}\text { Regiones } \\
\text { especificas sin } \\
\text { contradicolon } \\
\text { per se }\end{array}$ \\
\hline $\begin{array}{l}\text { Weng" } \\
\text { Osseotite 31 }\end{array}$ & $\begin{array}{l}\text { Unitarios/ } \\
\text { parciales } \\
\text { Maxilar sup. } 68 \\
\text { Mandibula } 3\end{array}$ & $\begin{array}{l}48 / 71 \\
\text { hasta } 18 \text { meses } \\
4 \text { perdidas } \\
\text { TEA } 93.5 \%\end{array}$ & & & & $\begin{array}{l}\text { Todos los } \\
\text { implantes se } \\
\text { colocaron en } \\
\text { aivéclos de } \\
\text { extraccion }\end{array}$ \\
\hline \multicolumn{7}{|c|}{$\begin{array}{l}\text { BS - Bránemark SVstem } \\
\text { TPS - Superficie de plasma titario } \\
\text { HA=Superficie de hidroxiapatita }\end{array}$} \\
\hline
\end{tabular}

Today they are generally used for any type of rehabilitation. Various studies have show that they integrate the same way the ones with a standard diameter do. Results have been published with 6 and 27 months of follow-up that oscillate between 93\% and $98 \%$ survival (English and Bohle 2003; Froum and cols. 2005; Cho and cols. 2007; Labarre and cols 2008). A study of 2,514 of these implants has a survival rate of $94.2 \%$ after 5 years.

The results of this study's $3.4 \mathrm{~mm}$ diameter implant survival rate $\quad$ (535 placed, 9 failed with $98.3 \%$ survival alter 2 years) are very acceptable. After analyzing the high survival rates of the implants published in the literature it seems that their use is very useful and guarantees good or better results, in any position of the mouth, than the implants with a standard $3.75 \mathrm{~mm}$ diameter (451 placed, 10 failed with $97.8 \%$ survival after 2 years). 
8. Cho SC, Froum SJ, et al. Immediate loading of narrow diameter implants with overdentures in severely atrophic mandibles. Practical Proccedings of Aesthethic Dentistry 2007;19:168-174.

9. Cochran DL, Mortin D, Weber HP. Consensus statements and recommended clinical procedure regarding loading protocols for endosseous dental implants. Int J Oral Maxillofac Imp/ 2004;19(Suppl):109-1.3

10. Davarpanah M, Martinez H, Kebir M, Etienne D, Tecucianu JF. Wide-diameter implants: new concepts. Int J Period Rest Dent 2001;21:149-159.

11. Dealemans P, Hermanns M, Godet F. Autologous bone graft to augment the maxillary sinus in conjunction with immediate endosseous implants: a retrospective study up to 5 years. Int J Period Rest Dent 1997;17:27-39.

12. English CE, Bohle GC. Diagnostic, procedural and clinical issues with the Sendax mini dental implant. Comp Cont Educ Dent 2003;24:3-25.

13. Froum SJ, Simon $\mathrm{H}$, et al. Histologic evaluation of bone implant contact of immediately loaded transitional implants after six to 27 months. J Oral Maxillofac Impl 2005;20:54-60.

14. Hourichi K, Uchida H, Yamamoto K, Sugimura M. Inmediate loading of Branemark system implants following placement in edentulous patiens: a clinical report. Int J Oral Maxillofac Impl 2000;15:824-839.

15. Labarre E, Alhstrom R, Noble W. Narrow diameter implants for mandibular denture retention. CDA Journal 2008;36:283-286.

16. Lam RV. Contour changes of the alveolar processes following extractions. J Prosth Dent 1960;10:25-32.

17. Lekholm U, Zarb GA. Patient selection and preparation. En: Branemark PI, Zarb GA, Albrektsson T. Tissue-integrated prostheses: osseointegration in Clinical Dentistry. Chicago: Quintessence 1985.

18. Maló P, Rangert B, Mech Eng, Nobre M. "All-on-four" Inmediate-function concept with Branemark system implants for completely edentulous Mandibles: a retrospective clinical study. Clin Impl Dent Relat Rese 2003;5(Suppl 1):2-9.

19. Moscovitch M. Molar restorations supported by 2 implants. An alternative to wide implants. / Canad Dent Ass 2001;67:535-9.

20. Petrungaro PS, Windmiller N. Using transitional implants during the healing phase of implant reconstruction. Gen Dent 2001;49:46-51.

21. Peñarrocha $M$, Uribe R, Balaguer J. Implantes inmediatos a la exodoncia. Situación actual. Med Oral 2004;9:234-242.

22. Pita Fernández S. Epidemiología. Conceptos básicos. En: Tratado de Epidemiología Clínica. Madrid; DuPont Pharma SA; Unidad de epidemiología Clínica, Departamento de Medicina y Psiquiatría. Universidad de Alicante. 1995;p.2547.

23. Shatkin TE, Shatkin $S$, y cols. Mini dental implants for long term fixed and removable prosthetics: a retrospective analysis of 2,514 implants placed over a fiveyear period. Com Cont Ed Dent 2007;28:92-100.

24. Smith DE, Zarb GA. Criteria for success of osseointegrated endosseous implants. J Prosth Dent 1989;62:567-72.
The current study of MG-OSSEOUS implants can be compared to other published studies in the literature, like those that are reflected in table 2 .

\section{Conclusions}

A good study protocol that is personalized for each one of these indicators assures good final results. Implants with narrow diameters can be used in any oral position including the molar zone, mainly in the superior maxilla, with a survival rate of 2 years similar to the standard. The oral hygiene of patients is a factor that seems to condition failure of the implants although it doesn't seem to be a determining factor in failed immediate post extraction implants. The use of wide diameter implants $(4.25 \mathrm{~mm})$ in post extraction cases could be a risk factor for failure.

\section{Acknowledgements}

To the Dres. Juan Luis Alonso de Dios, Luis Antonio Hernandez Martin, Luis Naval Gías, Carlos Orduña Domingo, Salvador Ortuño Laguia, Juan Jose Rodriguez Ortega, Angel Sancho Garcia, Fermin Terron Miron y Marcos Terron Gonzalez for your disinterested participation in this study. 